\title{
Edukasi Prinsip-prinsip Ekonomi Syariah kepada Pedagang dan Pelaku Usaha Mikro Kecil dan Menengah
}

\author{
${ }^{1}$ Ira Hasti Priyadi, ${ }^{2}$ Moh Syahri, ${ }^{3}$ Fithriyah Rahmawati \\ Institut Agama Islam Negeri Madura, Jl. Raya Panglegur Km. 4 Pamekasan 69371 \\ ${ }^{1}$ irahastipriyadi@iainmadura.ac.id, ${ }^{2}$ mohammadsyahri053@gmail.com \\ ${ }^{3}$ fithriyah@iainmadura.ac.id
}

\begin{abstract}
Nowadays, it is crucial to implement the principles of Islamic economics in our society. However, many traders and actors of micro, small, and medium enterprises (UMKM) do not yet have an adequate understanding of the implementation of the sharia principles in the transaction. Located in Erper Barat of Pasanggar Village, Pegantenan Subdistrict, Pamekasan, the understanding of business actors in the community is enhanced through the community engagement program (PKM). In this case, education is carried out simultaneously which results in the enhancement of people's knowledge in terms of sharia principles. Thus, they can apply sharia economic principles in their activities.
\end{abstract}

Keywords: Education, Sharia Economic, UMKM

\begin{abstract}
Abstrak
Penerapan prinsip ekonomi syariah di masyarakat menjadi hal yang sangat urgen pada saat ini. Namun demikian, banyak pedagang dan pelaku usaha mikro Kecil dan Menengah yang belum memiliki pemahaman yang cukup mengenai prinsip bermuamalah dengan prinsip syariah. Bertempat di Dusun Erper Barat Desa Pasanggar, Kecamatan Pegantenan, Kabupaten Pamekasan, pemahaman para pelaku usaha dan masyarakat ditingkatkan melalui program pengabdian kepada masyarakat (PKM). Dalam hal ini, edukasi dilakukan secara berkesinambungan sehingga pada akhirnya pengetahuan masyarakat lebih memadai. Dengan demikian, mereka bisa mengaplikasikan prinsip ekonomi syariah dalam kegiatan muamalah mereka.
\end{abstract}

Kata Kunci: Edukasi, Ekonomi Syariah, Pelaku Usaha, UMKM

\section{Pendahuluan}

Islam merupakan agama yang berisikan nasihat dan peraturan yang bertujuan untuk mengatur kehidupan manusia agar sesuai dengan disiplin dan cita-cita agama yang mengarah pada rahmatan lil alamin berarti agama islam berfungsi untuk memberikan keamanan dan kenyamanan bagi seluruh makhluk. Islam tidak pernah mempermasalahkan status yang disandang seseorang, apakah ia muslim ataukah non-muslim, dan disinilah letak perbedaan agama islam dengan yang lainnya. Karena islam adalah agama bagi seluruh alam. Islam telah mengatur seluruh perkara dengan peraturannya yang jelas, begitu juga dengan masalah muamalah (dalam hal ini adalah para pedagang dan pebisnis). 
Dalam berdagang ataupun berbisnis tentunya seseorang bebas dalam melakukan usaha perdagangan tersebut akan tetapi dalam lingkup keislaman ada beberapa prinsip yang harus diterapkan dalam melakukan sebuah usaha atau bisnis tersebut diantaranya ialah sesuai dengan prinsipprinsip ekonomi syariah yang sesuai dengan al-Qur'an dan Hadist. Karena dizaman sekarang ini banyak sekali seseorang ingin untung yang besar dalam usahanya akan tetapi tidak melihat pada aspek prinsip-prinsip yang sesuai dengan prinsip syariah seperti masih ada masyarakat yang menimbun barang, mengurangi takaran dan timbangan, dan riba.

Maka harus ada pembelajaran ataupun pendidikan bagaimana cara bermuamalah secara islami. Ekonomi Islam sebagai suatu IImu pengetahuan lahir melalui proses pengkajian ilmiah yang panjang, dimana pada awalnya terjadi sikap pesimis terkait eksistensi Ekonomi Islam dalam kehidupan masyarakat saat ini. Hal ini terjadi karena di masyarakat telah terbentuk suatu pemikiran bahwa harus terdapat dikotomi antara agama dengan keilmuan. Dalam hal ini termasuk didalamnya IImu Ekonomi, namun sekarang hal ini sudah mulai terkikis. Para Ekonom Barat mulai mengakui eksistensi Ekonomi Islam sebagai suatu IImu Ekonomi yang memberi warna kesejukan dalam perekonomian dunia dimana Ekonomi Islam dapat menjadi sistem Ekonomi alternatif yang mampu mengingatkan kesejahteraan umat, disamping sistem ekonomi kapitalis dan sosialis yang telah terbukti tidak mampu meningkatkan kesejahteraan umat (Al-Arif, 2011: 6).

Ekonomi Islam dibangun atas dasar agama Islam, karenanya ia merupakan bagian tak terpisahkan (integral) dari agama Islam. Sebagai derivasi dari agama Islam, Ekonomi Islam akan mengikuti agama Islam dalam berbagai aspeknya. Islam adalah sistem kehidupan (way of life), dimana Islam telah menyediakan berbagai perangkat aturan yang lengkap bagai kehidupan manusia termasuk dlam bidang Ekonomi. Setiap manusia bertujuan mencapai kesejahteraan dalam hidupnya, namun manusia memiliki pengertian yang berbeda-beda tentang kesejahteraan. Dalam berbagai literatur IImu Ekonomi konvensional dapat disimpulkan bahwa tujuan manusia memenuhi kebutuhannya atas barang dan jasa adalah untuk mencapai kesejahteraan (well-being). Manusia menginginkan kebahagiaan dan kesejahteraan dalam hidupnya, dan untuk inilah ia berjuang dengan segala cara untuk mencapainya (Pusat Pengkajian dan Perkembangan Ekonomi Islam Indonesia Yogyakarta atas Kerjasama dengan Bank Indonesia, 2008: 11).

Prinsip-prinsip ekonomi syariah adalah nilai-nilai yang harus diterapkan oleh pedagang ataupun UMKM agar sesuai dengan apa yang dianjurkan oleh agama islam agar tidak merugikan orang lain maka disini perlu ada edukasi ataupun pendidikan kepada pelaku UMKM dan para pedagang agar mengetahui bagaimana prinsip-prinsip ekonomi yang sesuai dengan syariah dan tidak ada yang dirugikan karena esensinya dalam muamalah itu adalah suka sama suka rela sama rela dengan berpatokan pada prinsip syariah. 


\section{Tinjauan Teoritis tentang Prinsip-prinsip Ekonomi dalam Islam}

Prinsip-prinsip ekonomi Islam yang merupakan bangunan ekonomi Islam didasarkan atas lima nilai universal yakni : tauhid (keimanan), 'adl (keadilan), nubuwwah (kenabian), khilafah (pemerintah) dan ma'ad (hasil). Kelima nilai ini menjadi dasar inspirasi untuk menyusun teori-teori ekonomi Islam (Karim, 2002: 17). Namun teori yang kuat dan baik tanpa diterapkan menjadi sistem, akan menjadikan ekonomi Islam hanya sebagai kajian ilmu saja tanpa memberi dampak pada kehidupan ekonomi. Karena itu, dari kelima nilai-nilai universal tersebut, dibangunlah tiga prinsip derivatif yang menjadi ciri-ciri dan cikal bakal sistem ekonomi Islami. Ketiga prinsip derivatif itu adalah multitype ownership, freedom to act, dan social justice.

$\mathrm{Di}$ atas semua nilai dan prinsip yang telah diuraikan di atas, dibangunlah konsep yang memayungi kesemuanya, yakni konsep Akhlak. Akhlak menempati posisi puncak, karena inilah yang menjadi tujuan Islam dan dakwah para Nabi, yakni untuk menyempurnakan akhlak manusia. Akhlak inilah yang menjadi panduan para pelaku ekonomi dan bisnis dalam melakukan aktivitasnya. Nilai- nilai Tauhid (keEsaan Tuhan), 'adl (keadilan), nubuwwah (kenabian) (Mujahidin, 2007: 14).

Beberapa Prinsip Dari ekonomi islam yang ditawarkan oleh M.A Choudhury (1986), yaitu sebagai berikut:

a. Tauhid dan persaudaraan. Tauhid adalah konsep yang menggambarkan hubungan antara manusia dan tuhanya segala aktivitas yang dilakukan olehseorang muslim akan sangat terjaga karena ia merasa bahwa Allah SWT. Akan selalu melihat apa yang dilakukannya. Sementara konsep persaudaraan atau yang bisa dikenal dengan ukhuwaah islamiyah memberikan makna persaudaraan dan kerja sama yang tulus antara sesama muslimdalam aktivitas ekonomi.

b. Bekerja dan produktivitas. Dalam ekonomi islam, individu dituntut untuk bekerja semaksimal mungkin dengan tingkat produktivitas kerja yang tinggi dengan tujuan memberikan yang terbaik bagi kemaslahatan umat. Hasil pekerjaan ini harus dikonpensasi secara layak sesuai dengan standar kehidupan yang layak.

c. Distribusi kekayaan yang adil. Meknisme pendistribusian kekayaan dalam islam adalah melalui mekanisme zakat, proses mekanisme zakat mampu melakukan redistribusi dari pihak kaya kepada pihak miskin (AlArif, 2015: 22).

\section{Pengertian Perdagangan dan UMKM}

a. Pengertian Dagang

Pedagang adalah orang yang melakukan perdagangan, memperjualbelikan barang yang tidak diproduksi sendiri, untuk memperoleh keuntungan (Sujatmiko, 2014: 231), Pedagang adalah mereka yang melakukan perbuatan perniagaan sebagai pekerjaan yang sehari-hari (Hasim, 2009: 2).

Pedagang adalah mereka yang melakukan perbuatan perniagaan 
sebagai pekerjaannya sehari. Perbuatan perniagaan pada umumnya adalah perbuatan pembelian barang untuk dijual lagi (Hasim, 2009: 15).

\section{b. Pengertian UMKM}

UMKM adalah usaha mikro kecil menengah yaitu usaha perdagangan yang dikelola oleh badan usaha atau perorangan yang merujuk pada usaha ekonomi produktif sesuai dengan kriteria yang di tetapkan oleh undangundang Nomor 20 Tahun 2008. Perbedaan usaha mikro, kecil, dan menengah (UMKM). Yaitu;

1) Usaha mikro

Adalah usaha produktif milik perseorangan dan/atau badan usaha perseorangan yang memenuhi kriteria usaha mikro yang diatur dalam undanng undang.

2) Usaha Kecil

Usaha ekonomi produktif yang berdiri sendiri dan dilakukan oleh perorangan atau badan usaha yang bukan merupakan anak perusahaan atau bukan cabang usaha yang dimilik, dikuasai atau menjadi bagian baik langsung maupun tidak langsung dari usaha menengah atau usaha besar yang memenuhi kriteria usaha kecil yang diatur dalam undangundang.

3) Usaha Menengah

Usaha ekonomi produktif yang berdiri sendiri, yang dilakukan oleh perorangan atau badan usaha yang bukan merupakan anak perusahaan atau cabang perusahaan yang dimiliki, dikuasai, atau menjadi bagian baik langsung maupun tidak langsung dengan usaha kecil atau usaha besar dengan jumlah kekayaan yang bersih atau hasi penjualan tahunan sebagaiman diatur dalam undang-undang("Pengertian, Jenis dan Perkembangan UMKM di Indonesia," 2020).

\section{Perilaku Pedagang dan UMKM}

Dalam kegiatan perdagangan dan UMKM (bisnis), pelaku usaha dan konsumen (pemakai barang dan jasa) sama-sama mempunyai kebutuhan dan kepentingan. Pelaku usaha harus memiliki tanggung jawab terhadap konsumen, karyawan komunitas dan lingkungan dalam segala aspek operasionalnnya.

Untuk itu perlu adanya aturan-aturan dan nilai-nilai yang mengatur kegiatan tersebut, agar tidak ada pihak-pihak yang dieksploitasi, terutama pihak konsumen yang berada pada posisi yang lemah. adapun yang perlu diperhatikan dalam perdagangan adalah perilaku pedagang.

Perilaku adalah pandangan-pandangan atau perasaan yang disertai kecenderungan untuk bertindak sesuai sikap objek. perilaku juga dapat disebut sebagai tingkah laku seseorang senantiasa didasarkan pada kondisi, yaitu tindakan mengenal atau memikirkan seseorang terlibat langsung dalam situasi memecahkan masalah. 


\section{Landasan Hukum}

Islam mengharamkan penghasilan melalui cara yang curang, seperti mengurangi takaran, timbangan, dan anak timbangan yang cacat. Perjanjian yang tidak jujur, curang dan penipuan adalah peraktek yang dilarang. Islam mengharamkan seluruh perjanjian bisnis yang didasarkan pada penipuan, kebohongan, sengaja disembunyikan, atau interpretasi yang salah atas suatu kebenaran. Dari uraian tersebut penjelasannya dalam Al-Qur'an (QS. Al- Mutaffifin ayat 1-4) sebagai berikut:

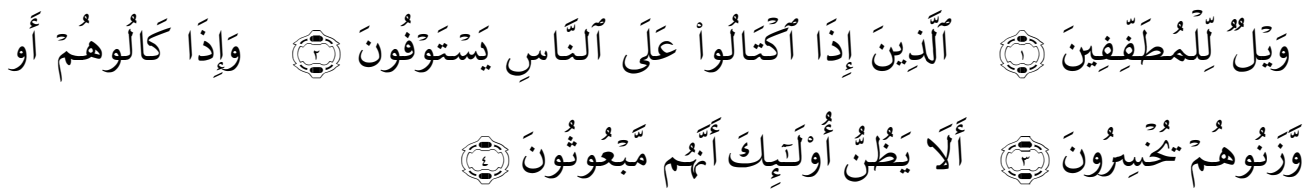

Artinya: "Kecelakaan besarlah bagi orang-orang yang curang. (Yaitu) orang-orang yang apabila menerima takaran dari orang lain mereka minta dipenuhi. Dan apabila mereka menakar atau menimbang untuk orang lain, mereka mengurangi. Tidaklah orang-orang itu menyangka, bahwa Sesungguhnya mereka akan dibangkitkan. (QS. 83: 1-4) (Yusuf, 2004: 70).

Yang dimaksud dengan orang-orang yang curang di sini ialah orangorang yang curang dalam menakar dan menimbang. Dari ayat diatas dapat disimpulkan bahwa salah satu yang dilarang dalam berdagang itu adalah curang dalam menimbang atau menakar.

Ayat tentang riba

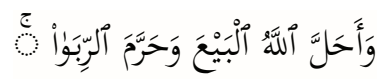

Artinya: Allah menghalalkan jual beli dan mengharamkan riba (Q.S Albaqoroh.

\section{Metode}

Pengabdian ini dilaksanakan dengan pendekatan pengabdian kepada masyarakat (PKM). Kegiatan ini bertempat di Dusun Erpes Barat Desa Pasanggar, Kecamatan Pegantenan Kabupaten Pamekasan. Adapun sasaran Kegiatan ini adalah para pelaku UMKM di Dusun Erpes Barat Desa Pasanggar, Kecamatan Pegantenan Kabupaten Pamekasan. Pengabdian ini menggunakan metode ceramah dan tanya jawab karena hakikat tujuannya adalah untuk memberikan eduaksi sehingga menambah wawasan bahwa dalam islam terhadap prinsip-prinsip bermuamalah.

\section{Hasil}

Pelaksanaan kegiatan Edukasi atau pendidikan dan pengarahan bagaimana prinsip-prinsip ekonomi islam kepada pedagang dan pelaku umkm, yang dilakukan di Dusun Erpes Barat Desa Pasanggar Kecamatan Pagantenan Pamekasan. Adapun objek pengabdian adalah masyarakat yang mempunyai usaha (pedagang dan pelaku umkm) seperti seorang yang 
mempunyai toko yang banyak menjual berbagai kebutuhan sehari-hari. Dan usaha kreatif seperti pengusaha krupuk rambak. Adapun Materi yang di sampaikan dalam pelaksanaan pembimbingan kepada masyarakat yang mempunyai usaha tersebut yaitu:

a. Tata cara muamalah yang benar sesuai dengan ajaran islam

b. Larangan riba

c. Larangan menimbun barang

d. Larangan memperjual belikan produk yang haram

e. Larangan dalam berlaku curang dalam timbangan dan takaran

f. Memberikan tips agar usahanya tambah berkembang

Inilah beberapa materi/tips yang kami sampaikan kepada narasumber untuk memberikan bagaimana cara prinsip-prisnsip ekonomi islam kepada pedagang dan pelaku umkm dalam bingkai keislaman. Adapun hasil edukasi atau pendidikan dari kami tentang bagaimana prinsip-prinsip ekonomi islam yang pada kesempatan kali ini kami berikan kepada tiga pelaku UMKM dan satu pedagang krupuk di Dusun Erpes Barat Desa Pasangger Kecamatan Pagantenan Pamekasan.yaitu sebagai berikut:

\section{a. Toko Milik Pak Suoko}

Toko ini memperjual belikan berbagai aneka kebutuhan sehari-hari seperti kebutahan sembako, kebutuhan rumah dan kebutuhan pertanian dan juga menjual bensin dll. Dimana dalam hal ini. Kami memberikan arahan dan dan strategi bagaimana jual beli yang baik dan tidak merugikan konsumen meliputi tidak menimbun barang, tidak melakukan transaksi riba dan juga tidak melakukan berbagai jual beli yang dilarang oleh islam dll. Dan tidak lupa kami memberikan tips juga bagaimana agar usahanya ini tambah maju yaitu dengan mendesain tempatnya sabagus mungkin dan lebih memperluasnya, karena ketika kami datang berkunjung kesana desain tokonya begitu sempit dengan barang-barang kebutuhan masyarakat disana begitu banyak, karena kenyamanan konsumen adalah bayaran bagi kepuasan konsumen tersebut. Sehingga perlu adanya desain tempat yang bagus agar konsumen lebih nyaman dan lebih leluasa berbelanja disana.

\section{b. Toko Milik Ibu Suaibah}

Toko ini sama seperti milik pak suoko yaitu menyediakan berbagai kebutuhan sehari-hari dan alat-lat pertania dll. Dimana dalam hal ini. Kami memberikan arahan dan dan strategi bagaimana jual beli yang baik dan tidak merugikan konsumen meliputi tidak menimbun barang, tidak melakukan transaksi riba dan juga tidak melakukan berbagai jual beli yang dilarang oleh islam dll. Karena toko ini lebih luas tempatnya dan desain tempatnya cukup bagus untuk masyararakat pedesaan dari pada objek yang sebelumnya maka disini kami hanya memberikan strategi pemasaran bagaimna cara pelayanan yang baik kepada konsumen, diantaranya mengedepankan akhlak, dan juga ramah dan lembut dalam memperlakukan konsumen. 


\section{c. Usaha krupuk Rambak Milik Pak Jumla}

Usaha ini kami memberikan nama usaha kreatif karena pak jumla disini merupakan satu-satunya pengusaha krupuk di Dsn, Erpes Barat Desa Pasnaggar ini, dan kami mewawancarainya bagaimana distribusi krupuk ini dan caraa memproduksinya, dan alhamdulillah sesuai dengan prinsipprinsip ekonomi syariah. Tidak melakukann kebohongan, tidak melakukan riba dll. Dan kami memberikan strategi pemasarannya agar ushanya tambah maju yaitu kami memberikan pemasaran digital. Yaitu pemasaran online lewat media sosial agar krupuknya semakin dikenal bukan hanya didaerah erpes barat desa pasanggar saja akan tetapi disetiap daerah.

\section{d. Kantin Sekolah Milik Mba Ma'i}

Ini merupakan kantin sekolah yang beraada di yayasan Ar-rohman Aleran Pasanggar dimana kantin disini berisi berbagai snack-snack dan aneka makanan ringan dan juga minuman yang targetnya yaitu anak-anak sekolah disana. Dimana dalam hal ini. Kami memberikan arahan dan dan strategi bagaimana jual beli yang baik dan tidak merugikan konsumen meliputi tidak menimbun barang, makanan yang cocok dan sehat untuk anak-anak, tidak melakukan transaksi riba dan juga tidak melakukan berbagai jual beli yang dilarang oleh islam dll, dan kami memberikan stategi pemasarannya yaitu dengan cara memberi perhatian lebih kepada anakanak yang membeli disana. Karena yang namanya anak-anak itu maunya disayang maka ketika anak-anak tersebut disayang maka akan timbul sebuah mahabbah (rasa cinta) dan anak-anak itu akan senang membeli disana.

Berikut ini adalah kegiatan Pengabdian di dusun Erpes barat Desa Pasanggar kecamatan Pegantenan:

Tabel 1. Kegiatan edukasi penerapan prinsip ekonomi syariah

\begin{tabular}{|c|c|c|c|}
\hline No & Tgl & Kegiatan & Keterangan \\
\hline 1. & $13-06-2020$ & $\begin{array}{l}\text { Memberikan } \\
\text { strategi } \\
\text { pemasaran } \\
\text { kepada } \\
\text { masyarakat yang } \\
\text { memiliki usaha } \\
\text { (umkm) sesuai } \\
\text { syariah }\end{array}$ & $\begin{array}{l}\text { Bertempat di toko bapak Suoko } \\
\text { dimana dalam hal ini kami } \\
\text { memberi arahan dan strategi } \\
\text { bagaimana jual beli yang baik } \\
\text { dan tidak merugikan konsumen } \\
\text { meliputi tidak menimbun barang } \\
\text { dan jual beli yang dilarang dan } \\
\text { larangan riba. }\end{array}$ \\
\hline 2. & $15-06-2020$ & $\begin{array}{l}\text { Memberikan } \\
\text { strategi } \\
\text { pemasaran } \\
\text { kepada } \\
\text { masyarakat yang } \\
\text { memiliki usaha } \\
\text { (umkm) sesuai } \\
\text { syariah }\end{array}$ & $\begin{array}{l}\text { Bertempat di toko Mba Ma i } \\
\text { pada kesempatan kali ini sedikit } \\
\text { berbeda dengan hari } \\
\text { sebelumnya karena toko ini } \\
\text { berjualan disekolah dan menjual } \\
\text { jajanan anak-anak, dan kami } \\
\text { mengajarkan bagaiamana cara } \\
\text { agar disenangi anak-anak agar }\end{array}$ \\
\hline
\end{tabular}


3. 19-06-2020 Mengubah mindset perantau menjadi entrepreneur membeli didsana akan tetapi tak melupakan hal-hal yang dibahas di toko sebelumnya.

$\begin{array}{ll}\text { 27-06-2020 } & \text { Memberikan } \\ & \text { strategi } \\ & \text { pemasaran } \\ & \text { kepada } \\ & \text { masyarakat yang } \\ & \text { memiliki usaha } \\ & \text { (umkm) sesuai } \\ & \text { syariah }\end{array}$

4. $27-06-2020$
Sasaran kami para mantan perantau muda dan juga istri perantau, dengan cara mendatangi satu persatu, kami mensosialisasikan bagaimana cara menjadi enterpreniur agar tertanam di benak mereka jiwa pengusaha bagi mereka yag pulang dari perantauan yang hanya membangun rumah habis itu berangkat lagi.

Bertempat di sebuah rumah yang memiliki usaha krupuk yaitu bapak jumla pada kesempatan kali ini sedikit berbeda dengan sosialisai di minggu sebelumnya, kami melakukan sosialisai baagaimana penjualan atau pemasaran sesuai prinsip syariah di Dusun erpes barat dimana kegiatan kali ini kami berkunjung ke pemilik usaha yaitu bapak jumla yaitu usaha krupuk, kegiatan ini sengaja kami ambil karena meihat musim-musim sekrang ini bahan pokok dan bahan bakar naik turun, dan juga seiring dengan adanya covid-19 ini perekonomian menurun, dikhawatirkan mereka mengambil kesempatan di balik hal ini dan menjualnya dengan idak syari at.

\section{Kesimpulan}

Pada dasarnya, pelaku usaha yang yang menjadi sasaran pengabdian ini sangat antusias dan memberikan kesan yang positif terhadap pelaksanaan pemberian edukasi mengenai prinsip ekonomi syariah. Dengan demikian, mereka lebih memahami prinsip-prinsip tersebut untuk diaplikasikan dalam kehidupan sehari-hari. Dalam pelaksanaan edukasi, 
penulis juga sangat hati-hati menyampaikan ide-ide mengenai prinsip eonomi Islam untuk menghindari gesekan dan ketersinggungan dengan para pelaku usaha.

Namun demikian, pemahaman tentang prinsip-prinsip ekonomi islam di Dusun Erpes Barat Desa Pasanggar masih perlu pembinaan khusus karena mayoritas pelaku usaha hanya memahami secara praktik dan berdasarkan pengalaman. Maka dari itu, perlu adanya pembinaan secara khusus dan mendalam mengenai pelaksanaan muamalah dengan prinsip syariah dan tidak bertentangan dengan hukum negara berdasarkan undang-undang. Dalam hal ini, yang menjadi sasaran diharapkan tidak hanya para pelaku usaha seperti pedagang dan pelaku UMKM, tapi masyarakat luas juga sangat perlu dilibatkan.

\section{Daftar Pustaka}

Al-Arif, M. N. R. (2011). Dasar-Dasar Ekonomi Islam. Solo: PT. Era Adicitra Intermedia.

Al-Arif, M. N. R. (2015). Pengantar Ekonomi Syariah. Bandung: Pustaka Setia.

Choudhury, M. A. (1986). Contributions to Islamic Economic Theory: A Study in Social Economics. Jerman: Springer.

Hasim, F. (2009). Hukum Dagang. Jakarta: Sinar Grafika.

Karim, A. (2002). Ekonomi Mikro Islami. Jakarta: III T.

Mujahidin, A. (2007). Ekonomi Islam. Jakarta: Raja Wali Press.

Pengertian, Jenis dan Perkembangan UMKM di Indonesia. (2020, Februari 1). Diambil 3 September 2020, dari Jurnal website: https://www.jurnal.id/blog/pengertian-jenis-dan-perkembangan-umkmdi-indonesia/

Pusat Pengkajian dan Perkembangan Ekonomi Islam Indonesia Yogyakarta atas Kerjasama dengan Bank Indonesia. (2008). Ekonomi Islam. Jakarta: PT. Raja Grafindo Persada.

Sujatmiko, E. (2014). Kamus IPS (Vol. 1). Surakarta: Aksara Sinergi Media. Yusuf, M. A. (2004). Kaya Karena Allah. Tangerang: PT. Kawan Pustaka. 